Rifat N. Bali

\title{
Antisemitism in Turkey: A New Phenomenon or More of the Same?
}

In the year 1989, Turkish and Jewish business leaders came together with the leaders of Turkey's Jewish community and a number of retired Turkish diplomats to establish the Quincentennial Foundation, a non-profit organization formed to commemorate the five-hundredth anniversary of Jewish life in the Ottoman Empire and Turkey. One branch of the organization was established in New York City, the apparent purpose of which was to hold similar events in the United States as well. ${ }^{1}$

The message that was repeatedly relayed to public opinion at all of the foundation's events that took place in Istanbul-and especially the ones in New York City and Washington, DC-over the four-year period between 1989 and 1992 was as follows: the Ottoman Empire and its successor state the Republic of Turkey were and are a tolerant nation, one which has served as a refuge for all manner of refugees throughout its history. Offered as the most brilliant examples of this tolerance were the Ottoman welcoming of many Spanish, or "Sephardi" Jews after their expulsion from Spain in 1492 in the wake of the Reconquista and the rescue by Turkish diplomats of dozens of Jews during the Second World War. In light of such actions, Turkey was put forward as one of the rare Islamic states where antisemitism did not exist. The official aim of this pitch was not so much to glorify-and certainly not to critically examine-the past as to put a positive face on the present. By commemorating and celebrating instances of Turkey and the Turks' historic tolerance, the true if unofficial purpose was to shore up the image of the Turkish Republic among the US public and its politicians and to thereby counter the decade of efforts by various Armenian-American organizations to lobby the White House and Congress to officially acknowledge the Armenian genocide.

In the public relations campaign developed by the Turkish regime in conjunction with the leaders of the country's Jewish community, the message to leading American opinion-makers was clear: a nation that could behave with

1 For a detailed study of the foundation and its activities, see R. N. Bali, Model Citizens of the State:The Jews of Turkey During the Multi-Party Period, trans. P. F. Bessemer (Madison: Fairleigh Dickinson University Press, 2014), 310-29.

Ә OpenAccess. ( 2021 Armin Lange, Kerstin Mayerhofer, Dina Porat, Lawrence H. Schiffmann, published by De Gruyter. (cc))BY-NC-ND This work is licensed under the Creative Commons Attribution-NonCommercialNoDerivatives 4.0 International License. https://doi.org/10.1515/9783110671964-014 
such tolerance toward its Jewish minority could not have committed the crimes against humanity that it has been accused of, namely, the Armenian genocide. ${ }^{2}$

Of course, this account has little or no connection with Turkey's historical reality, since there have been various forms and manifestations of antisemitism in Turkey since the Republic was declared in 1923. Regardless of which party was in power or what political view held sway, Turkey's Jewish population has faced discrimination and been treated in many ways as de facto second-class citizens. Moreover, one of the unintended results of the Quincentennial Foundation's various activities between 1989 and 1992 was the increased visibility of Turkish Jews within the public sphere, which often brought harsh reactions from the Islamist sector and, ironically, thereby served as a stimulus to the significant increase in antisemitic literature and publications in Turkey. ${ }^{3}$

In the elections held exactly one decade after the end of the Quincentennial's activities in 1992, Turkey elected its first ever Islamist government by a large margin. The Justice and Development Party or AKP had begun as a breakaway Islamist party, separating itself from the Islamist-Nationalist "National Vision" (Milli Görüş) movement of Necmettin Erbakan, the founding father of political Islam in Turkey, and repudiating the political past of Turkey's Islamists while still retaining Islamist values and references, and preferring to style itself as an Islamic version of Europe's various Christian Democratic parties. The AKP would go from strength to strength, handily winning successive elections in 2007, 2011, and 2015. The international press would publish frequent articles on how the secular Turkish Republic was being transformed under an Islamist government, and this interest would be increased further by the attempted coup d'état by a military cabal in 2016. Another frequent Turkish subject taken up by the international press were that reports of increasing antisemitism in Turkey under AKP leader Recep Tayyip Erdoğan and the resulting exodus of Turkey's Jews.

But is this really the case? This is what I would like to discuss in my article.

\section{Antisemitism During the Single Party Period (1923-1946)}

Antisemitism has existed in Turkey from the establishment of the Republic in 1923 to our day. It has manifested itself in various forms and manners over this time, depending on the period according to the ideological currents then

2 Cf. ibid., $268-300$ and $310-29$.

3 Ibid., 324-25. 
dominant. During the so-called Single Party Period (1923-1945), during which time Mustafa Kemal Atatürk and his colleagues ran the country within the framework of the Republican Peoples Party they founded, and with the expressed aim of "secularizing" Turkish society, antisemitism was most clearly expressed in the economic and cultural spheres. During these years, frequent criticism was leveled at Turkish Jewry for not assimilating or "Turkifying” themselves as quickly as desired by the regime and for preferring to speak their native language of Ladino or the French they learned in Alliance schools to Turkish. Behaving in such a fashion, the argument went, showed an ingratitude toward their Turkish hosts, as they showed themselves as having either forgotten or disregarded the goodness and tolerance they were shown by the Ottoman Turks in welcoming them from Spain in $1492 .{ }^{4}$ The caricatures of the Jewish couple Salamon and Rebeka found in the humor magazines of the era were practically indistinguishable from the Nazi caricatures of the period. Salamon is portrayed as a somewhat seedy, hook-nosed, miserly shyster, who is obsessed with money and speaks Turkish with a thick "Jewish" accent. ${ }^{5}$ This atmosphere of hostility would be the backdrop for two important anti-Jewish incidents in Turkey.

In the first of these, a series of pogroms conducted against the Jewish population of Eastern Thrace would occur in July 1934, in areas of dense Jewish settlement and in reaction to what was seen as Jewish domination of the local economy. In the response to threats, looting, and actual expulsions, a significant portion of the area's Jews were forced to either abandon their homes and property or sell them at a significant loss and migrate to Istanbul. ${ }^{6}$

The second event was the passage of the Capital Tax Law (Varllk Vergisi Kanunu) in November 1942. This law, which was imposed in a strikingly arbitrary and discriminatory fashion against the country's non-Muslim minorities, imposed a far greater assessment of "taxable" wealth on non-Muslims than on Muslims of comparable wealth. Hundreds of Turkish non-Muslim citizens were thus forced to dispose of their property at bargain-rate prices in order to pay

4 For a detailed study, see R. N. Bali, Cumhuriyet Ylllarnnda Türkiye Yahudileri: Bir Türkleştirme Serüveni (1923-1945) (Istanbul: İletişim Yayınları, 1999) [in Turkish].

5 Cf. H. Bayraktar, Salamon und Rabeka: Judenstereotype in Karikaturen der türkischen Zeitschriften "Akbaba," "Karikatür” und "Milli Inkilap" 1933-1945 (Berlin: Klaus Schwarz, 2006); L. Olivier-Mallet, “Karikatür Dergisinde Yahudilerle İlgili Karikatürler (1936-1948),” Toplumsal Tarih 34 (October 1996): 26-33 [in Turkish].

6 See R. N. Bali, 1934 Trakya Olaylan, 2nd ed. (Istanbul: Libra Kitap, 2012) [in Turkish]; B. Pekesen, Nationalismus, Türkisierung und das Ende der jüdischen Gemeinden in Thrakien, 19181942 (Munich: Oldenburg, 2012); H. Bayraktar, "Zweideutige Individuen in Schlechter Absicht": Die antisemitischen Ausschreitungen in Thrakien 1934 und ihre Hintergründe (Berlin: Klaus Schwarz Verlag, 2011). 
the heavy tax assessment imposed on them. Those unable to do so were apprehended and sent to Eastern Anatolia to toil in road construction under harsh winter conditions. ${ }^{7}$

\section{Antisemitism During the Multi-Party Period}

As World War II was drawing to a close, Turkey began to take steps toward the establishment of a multi-party democracy. After the rushed election of 1946 meant to preserve the ruling party's majority, a second election, held in 1950, managed to bring the opposition to power for the first time since the Republic's inception. The new Democrat Party, established by a group of disillusioned RPP members, espoused liberal democratic values and adopted an extremely positive approach toward the country's various minorities.

However, the DP's rise to power also witnessed a new phenomenon of political parties making concessions to the country's more traditional and religious elements, particularly in regard to easing the RPP's heretofore strict interpretation of the principle of secularism.

The DP's laxer approach toward secularism (as well as that of subsequent parties) served as a tacit admission that Atatürk's social engineering project of transforming an essentially Islamic society into a secular one had not been popular or planted deep roots among the majority of the population.

Even after the DP was toppled and disbanded by the military coup of 1960, the process of "de-laicization" it had begun and which we might characterize as Turkish society "returning to its fundamental cultural codes," would be continued by its various successor parties (Justice, Motherland, and True Path Parties) in the following decades.

In parallel to the trend among rightist politicians to increasingly cater to the sensibilities of the broad conservative and Muslim voting public for electoral gain, Necmettin Erbakan (1926-2011), a professor of mechanical engineering and President of the Union of Chambers and Commodity Exchanges of Turkey (Türkiye Odalar ve Borsalar Birliği Başkanı) whose political Islam competed for those same voters, would establish his "National Vision" movement (Milli Görüss) in 1969 and enter the Turkish political stage as the chairman of his newly created Nationalist Order Party (Milli Nizam Partisi). Although the party

7 For sources in English, see R. N. Bali, The Wealth Tax (Varlk Vergisi) Affair: Documents From the British National Archives (Istanbul: Libra Kitap, 2012); R. N. Bali, The "Varlk Vergisi" Affair: A Study On Its Legacy-Selected Documents (Istanbul: The Isis Press, 2010); F. Ökte, The Tragedy of the Capital Tax, trans. G. Cox (London: Croom Helm, 1987). 
was eventually closed down after being ruled as having "behaved in contradiction to the principle of secularism," it would be re-formed under different names (and shut down) a number of times throughout Erbakan's life, even surviving its founder in the current form of the Felicity Party (Saadet Partisi). ${ }^{8}$

One of the main characteristics of the "National Vision" movement has been its antisemitism. Its members, including Erbakan himself, as well as its party organ Millî Gazete frequently make use of antisemitic themes, including references to the Protocols of the Elders of Zion and its claims of Jewish and Zionist world domination. They have also adapted these to local use, repeating ad nauseum the claims that the collapse of the Ottoman Empire and establishment of the State of Israel were both the result of a Dönme-Jewish-Zionist plot. ${ }^{9}$

Yet, despite the apparent extremism of much of his thought, the father of the National Vision movement Necmettin Erbakan was no marginal player in Turkish politics. Erbakan served as minister without portfolio and deputy prime minister in the first and second so-called "Nationalist Front" governments (March 31, 1975 to June 21, 1977 and July 21, 1977 to January 5, 1978, respectively), as well as prime minister in the Refahyol coalition government (June 1996-June 1997). When he passed away on February 27, 2011, Erbakan was given an official state funeral that was attended by all of the top government officials. Not unsurprisingly, Erbakan is remembered as a sympathetic, jocular, and slightly eccentric figure in Turkish political life, and referred to as "hoca," a term of respect used for both secular and Islamic religious scholars. His literally thousands of antisemitic utterances are simply seen by the public as the eccentricities of an otherwise upright politician and not to be taken too seriously. Indeed, not a single one of the dozens of eulogies written after his demise mentioned his antisemitism. Indeed, Erbakan's image as an “elder statesman” remains so powerful and unimpeachable that there is even a university in Konya named after him. Moreover, the antisemitic rhetoric of Erbakan and his "National Vision" ideology have never been subject to criticism per se within any sector of Turkish society or politics, nor has anyone of prominence dared to characterize the founder of Turkish political Islam as an "antisemite"; it has been easier to simply ignore it.

8 The different political parties were the National Order Party (Millî Nizam Partisi, or MNP) 1970 - 1972, The National Salvation Party (Milli Selamet Partisi, MSP) 1972-1981, the Welfare Party (Refah Partisi, RP) 1983-1998, the Virtue Party (Fazilet Partisi, FP) 1997-2001, and finally, the Felicity Party (Saadet Partisi, SP) 2001-present.

9 For a study of these themes, see R. N. Bali, Antisemitism and Conspiracy Theories in Turkey (Istanbul: Libra Kitap, 2013). 


\section{The AKP, Recep Tayyip Erdoğan, and Antisemitism}

Established on August 14, 2001, the vast majority of Justice and Development Party (Adalet ve Kalkınma Partisi, or AKP) founders, including prime minister Recep Tayyip Erdoğan and his successor Abdullah Gül, were breakaway politicians from Erbakan's National Vision movement. ${ }^{10}$ Erdoğan and his colleagues had cut their teeth within this movement and were imbued with its cultural codes. As such, they were no strangers to the antisemitic currents that had so influenced the older generation of Islamist politicians.

Erdoğan himself had spent the 1970s as the head of the National Salvation Party's Youth Division, and it is a commonly known fact that he once wrote and directed a play called "Mas-Kom-Yah," short for "Masons, Communists, and Jews"-the "three great enemies" of Islam, Turkey, and the World as defined by the National Vision movement. ${ }^{11}$ Even so, Erdoğan is not simply a younger version of Erbakan. The principal difference between Erbakan and himself is that Erbakan and his political associates believe in "Jewish World Domination" and therefore see "a Jewish hand" behind every negative development. Despite his clear antipathy for both Jews and the State of Israel, Erdoğan's hostility is simply not on this same level of obsession. The difference can also be seen in Erdoğan's far greater display of political pragmatism than that shown by his former mentor. Nevertheless, over time Erdoğan's speech, when discussing Zionism, Jews, or Israel has, like that of Erbakan before him, increasingly taken on an antisemitic tone and hue. ${ }^{12}$ Thus, in a 2014 speech before the Washington-based Council of Foreign Relations the Turkish president would feel obliged to make the following declaration:

10 The AKP's official website is https://www.akparti.org.tr/en. For a selected number of English titles on the AKP and Erdoğan, see: M. H. Yavuz, ed., The Emergence of A New Turkey (Salt Lake City: University of Utah Press, 2006); Ü. Cizre, ed., Secular and Islamic Politics in Turkey: The Making of the Justice and Development Party (London: Routledge, 2007); E. Axiarlis, Political Islam and the Secular State in Turkey: Democracy, Reform and the Justice and Development Party (New York: I. B. Tauris, 2014); S. Çağaptay, The New Sultan: Erdogan and the Crisis of Modern Turkey (New York: I. B. Tauris, 2017).

11 Ö. Karslı and K. Butakım, “Ve Erdoğan sahnede!” Vatan, May 2, 2012 [in Turkish].

12 Raphael Ahren, "Erdoğan Calls Zionism a 'Crime against Humanity,” The Times of Israel, February 28, 2013, https://www.timesofisrael.com/erdogan-calls-zionism-a-crime-against-hu manity/. 
I am very sad to see that my country, myself, and my colleagues, sometimes, are labeled as being anti-Semitic. But Turkey, in no part of its history, has ever been racist. It has never been anti-Semitic in any time in its history at all. I am one of the first prime ministers in the world to have declared anti-Semitism to be a crime against humanity. Turkey, its people and its state, have always stood by the oppressed. When the Jews were under pressure or oppressed, Turkey extended a helping hand to them. When the Jews were expelled from Spain in the fifteenth century, they sought refuge in the Ottoman territory and they lived peacefully in this land for centuries. Similarly, our country embraced the Jews fleeing Hitler's persecution. There are times when I personally am labeled as an anti-Semitic person. Criticizing Israel's massacres that defy international law, trample on human rights and life is not anti-Semitism. Holding a state responsible that massacres 10 people by stopping an international Gaza-bound aid flotilla isn't anti-Semitism. It isn't anti-Semitism either to criticize an administration that massacres innocent babies and children in their homes, mosques, hospitals, schools, beaches and parks without any discrimination. Our criticism is not directed at the Jews at all. It is only and solely directed at the Israeli administration and its policies, and let no one distort this. ${ }^{13}$

The antisemitism present in Erdoğan's “New Turkey” is of a qualitatively different character than that of previous eras. During the current period, clearly antisemitic journalists and authors are often held in great honor and esteem. Indeed, they have traveled with the president's official retinue on his overseas trips, have been invited to be hosts of Erdoğan in his informal Presidential Talks at the Presidential Palace with Turkey's leading intellectuals, ${ }^{14}$ and honored with prizes and awards. ${ }^{15}$ Some of these journalists have taken part in the socalled "Committee of the Wise Persons" (Akil Insanlar Heyeti) formed to find a

13 N. N. “Erdoğan, CFR'da konuştu,” Sputnik News, September 23, 2014, https://tr.sputniknews. com/rsfmradio.com/2014_09_23/erdogan-cfr-konusmasi/ [in Turkish, no longer available]; R. Ahren, "Erdogan Rebuffs Anti-Semite Claims but Lashes Israel for 'Massacre', The Times of Israel, September 23, 2014, https://www.timesofisrael.com/erdogan-rebuffs-anti-semite-claimsbut-lashes-israel-for-massacre/; "President Erdoğan Addresses CFR," Presidency of the Republic of Turkey, issued September 23, 2014, https://www.tccb.gov.tr/en/news/542/3249/president-er dogan-addresses-cfr.html.

14 Mehmed Şevket Eygi (Pro Erbakan's Millî Gazete's columnist) and Kadir Mısıroğlu were invited, cf. Z. Gürcanlı, “Cumhurbaşkanı Sofrasına Mısıroğlu'nun davetine CHP'den sert tepki,” Hürriyet, August 18, 2015, http://www.hurriyet.com.tr/cumhurbaskani-sofrasina-misiroglunun-dave tine-chpden-sert-tepki-29844266 [in Turkish].

15 In October 2017, Nurettin Topçu (1909-1975) a rightist intellectual known for his antisemitic writings was among the recipients of the Turkish Presidency Great Prizes of Culture and Art. In 2014 Alev Alatlı (1944-), also known for her antisemitic writings, was among the recipients of the Prizes. 
solution to the Kurdish problem. ${ }^{16}$ Among the founding fathers of the Islamist and Nationalist current in Turkey, both Erdoğan and his successor as prime minister, Abdullah Gül, have respectfully referred to the antisemitic author and poet Necip Fazıl Kısakürek with the honorific "üstad" ("master") adjective, and President Erdoğan has handed out cultural and artistic awards named after him at ceremonies organized by the pro-AKP daily Star. ${ }^{17}$ Due to the AKP's overwhelming parliamentary majority and apparently unassailable hold on political power, newspaper columnists who support the party have gained the confidence to express their antisemitic views more openly. Usually, this takes the form of disseminating conspiracy theories regarding current events in which either Jews, Israel, or the United States play a central role. During the popular disturbances in Istanbul in June 2013, surrounding the attempted destruction of Gezi Park, one of the city's few remaining green spaces, the claim was often heard of a "mastermind," a veiled hint to a Jewish conspiracy, directing events in order to destabilize Turkey. As such, it was simply an updating of the "American-Zionist plot to destroy Turkey" conspiracy mentioned so frequently by Erbakan in the 1970s. The progovernment A Haber television station even made it the subject of a documentary, ${ }^{18}$ and the president's chief advisor Yiğit Bulut embraced the idea publicly. ${ }^{19}$

The fifteen-year period in which the AKP and, more specifically, Erdoğan have been in power have been a period increasingly described publicly as the latter's "imperial reign." The most frequent reference is to the Ottoman Sultan Abdülhamid II, known in the West as "the Red Sultan" and more affectionately to the Islamists as "the Great Ruler" (Ulu Hakan), an historical figure who embodies the country's past glories and who has become the subject of an ongoing

16 Abdurrahman Dilipak and Hasan Karakaya from the daily Yeni Akit, both known for their antisemitic writings, were included in this committee. See Ü. Kozan, “İşte Akil İnsanlar Heyeti," Hürriyet, April 4, 2013, http://www.hurriyet.com.tr/iste-akil-insanlar-heyeti-22957853 [in Turkish]. 17 “4. Necip Fazıl Ödülleri sahiplerini buldu," Sabah, December 15, 2017, https://www.sabah. com.tr/kultur-sanat/2017/12/15/4-necip-fazil-odulleri-sahiplerini-buldu [in Turkish].

18 “Islamist Turkish President Erdoğan Says A 'Mastermind' Is Plotting Again Turkey,” MEMRI, Special Dispatch no. 6021, issued April 14, 2015, accessed August 7, 2020 https://www.memri. org/reports/islamist-turkish-president-erdogan-says-mastermind-plotting-against-turkey-anti semitic; "Turkish Film 'Mastermind' Purports to Reveal Jewish Conspiracy," YnetNews, May 2, 2015, https://www.ynetnews.com/articles/0,7340,L-4652817,00.html; Y. Rosenberg, "Will Obama Condemn The Mainstreaming of Anti-Semitism by Turkey’s Ruling Party?,” Tablet Magazine, March 20, 2015, http://www.tabletmag.com/scroll/189783/will-obama-condemn-the-mainstream ing-of-anti-semitism-by-turkeys-ruling-party.

19 "Yiğit Bulut: Türk ekonomisinden tek çakıl taşı koparamayacaklar," Haberler, September 26, 2016, https://www.haberler.com/yigit-bulut-turk-ekonomisinden-tek-cakil-tasi-8804639-haberi/ [in Turkish]. 
drama produced by Turkish state television (TRT 1) Payitaht: Abdülhamid, in which the sultan's life is portrayed against the backdrop of a Zionist conspiracy to topple the Ottoman Empire. Unsurprisingly, the series has been wildly popular within both Islamist and nationalist circles where the belief in such a Zionist plot to bring down the sultan in revenge for his refusal to grant Palestine to Theodor Herzl is widely and uncritically accepted. ${ }^{20}$

\section{Positive Developments During the AKP Era}

Despite all of the aforementioned negative developments during the period of AKP rule, we should also mention three "positive" ones. The first of these is that, with the AKP's repeated electoral victories and total control of the national government, the once widespread claim that "the Islamists cannot come to power in Turkey because the Sabbateans are in control of the state apparatus" has finally been laid to rest. Similarly, one no longer hears among the Islamist press the claims that Atatürk himself was of Dönme (and hence, Jewish) origin and that it was due to this that he abolished the Caliphate and established a secular state, or, in their words, a "Jewish Republic." 21 The reason for this sudden silence is simple: if the thus far unprecedented electoral success of the AKP since November 2002 is understood as "a popular revolt by political Islam against the Kemalist order" then the lack of active resistance and ease with which it was carried out makes such claims of "Sabbatean hegemony" all the more hollow.

The second "positive" development of this era is that, when the various antisemitic utterances and publications target Turkish Jewry Prime Minister [and now President] Erdoğan has intervened, making declarations to assure the country's Jews that they are under the state's protection along the lines of "they are our [fellow] citizens, our brethren that the Jewish world entrusted to us."22

20 "Turkish State-Owned Network Airs Television Drama Series," MEMRI, Special Dispatch no. 7027, issued July 26, 2017, accessed August 7, 2020, https://www.memri.org/reports/turkishstate-owned-network-airs-television-drama-series-depicting-jews-murderous-and; H. E. Cohen Yanarocak, "Decoding the 'Payitaht Abdülhamid'," Turkeyscope 1, no. 5 (March 2017): 4-7, https://dayan.org/content/decoding-payitaht-abd\%C3\%BClhamid.

21 For more on this matter, see R. N. Bali, A Scapegoat For All Seasons: The Dönmes or CryptoJews of Turkey (Istanbul: The Isis Press, 2008); M. D. Baer, “An Enemy Old and New: The Dönme, Anti-Semitism, and Conspiracy Theories in the Ottoman Empire and Turkish Republic," Jewish Quarterly Review 103, no. 4 (2013): 523-55.

22 “Turkey's Jews are under my protection: Turkish Prime Minister," Hürriyet, June 22, 2012, http://www.hurriyetdailynews.com/turkeys-jews-are-under-my-protection-turkish-pm-23788; 
Finally, the third "positive" development has been the success of the AKP regime of acting on principle that no secular Turkish political party has ever succeeded in doing while in power: under the AKP, Turkey has returned community properties previously confiscated by the state to the various minority communities to whom it originally belonged. ${ }^{23}$

\section{“Antisemitism Grew During the Erdoğan Period"... or did it?}

The claim, often repeated in recent years, that "antisemitism has increased since Erdoğan has come to power" is partially valid and partially not. ${ }^{24}$ It is true that, in comparison with previous eras, antisemitic publications and public declarations have increased, but the principal reason for this is the explosion of communication in general as Turkey has entered the digital age. Antisemitism was widespread even before this period, but its visibility has grown with increased online access. Today, with the internet, it is no longer necessary to actually purchase a newspaper in order to read newspaper columnists, whether from the Islamist sector or elsewhere. In the pre-digital age, a person could not simply broadcast their views to the general public, but in the digital age all persons-not just journalists and authors-are free to respond to news items and opinion pieces and to offer their own commentaries, opinions, and analyses to anyone and everyone. In this way, an unanticipated if also unsubstantiated truth has come to light. Through the internet, it can now be clearly seen that antisemitism pervades the very core of Islamist and nationalist thought in Turkey. The decade-and-ahalf of AKP rule has given the large Islamist base, where an atmosphere of hos-

\footnotetext{
"Government pledges to ensure the safety of Jewish Community in Turkey,” Daily Sabah, July 26, 2014, https://www.dailysabah.com/politics/2014/07/26/government-pledges-to-take-care-of-jew ish-community-in-turkey.

23 AKP claims that it returned two billion dollars worth of property to the minorities, cf. S. Wilson, “At a Breaking Point in Turkey: Should Jews Stay or Should We Go?” Jewish Journal, March 18, 2015, http://jewishjournal.com/cover_story/164955/.

24 See for example R. Ahren, “Turkish MP: Erdoğan's anti-Semitism Difficult to Reverse,” The Times of Israel, February 5, 2014, https://www.timesofisrael.com/turkish-mp-erdogans-antisemitism-difficult-to-reverse/; B. Johnson, “Anti-Semitism in Erdoğan's Turkey is a Feature, not a Bug,” Fox News, October 25, 2017, http://www.foxnews.com/opinion/2017/10/25/anti-semitism-inerdogan-s-turkey-is-feature-not-bug.html; M. D. Baer, "Erdogan Accuses Germany of Echoing the Nazis-But his own Record on anti-Semitism is Shameful," LSE European Politics and Policy (EUROPP) Blog, April 13, 2017, http://eprints.lse.ac.uk/75701.
} 
tility toward both Israel and Jews prevails, an overweening self-confidence. This has resulted in its writers, journalists, and opinion leaders expressing their ideas with an unhesitating sense of freedom and lack of restraint.

The argument that the Erdoğan regime has fanned the flames of antisemitism is one that has been generally used in the international media by Turkish journalists opposed or hostile to Erdoğan and the AKP. ${ }^{25}$ For these writers, "antisemitism" has become a tool for criticizing Erdoğan and for further tarnishing the already tarnished image of the Turkish leader in the eyes of the West. ${ }^{26}$ Unlike Turkey, the western world-and the United States and Israel in particularhave long been sensitive to antisemitism, and thus reports of Turkish antisemitism, despite its ubiquitous quality, always possess "news value" and can thus be easily resorted to by the western press.

Let us now return to my opening remarks. It is more than a little ironic that, whereas in 1992, when the Quincentennial celebrations were in full swing, antisemitism in Turkey was written off as insignificant, marginal, or its existence even denied outright for the sake of political expediency. In the current period, its existence is now stressed-sometimes exaggeratedly so-by those opposed to Erdoğan and the AKP, and not out of actual concern for its victims, but once again for the purpose of political expediency. At the end of the day, the widespread and deeply rooted antisemitism within a significant part of Turkish society is not a new phenomenon. It was of a similarly ubiquitous nature in earlier periods, but in the pre-digital age it was not as readily apparent. Now, however, a malignant and serious antisemitism has become so routine and commonplace as to not even draw a reaction. Whether out of fear, fatigue, or simply apathy, no one seems willing to confront the phenomenon or take a moral accounting.

25 B. Bekdil, "How Turkey Plans to 'Combat Anti-Semitism', Middle East Forum, Septeber 25, 2014, http://www.meforum.org/4833/how-turkey-plans-to-combat-anti-semitism; B. Bekdil, "Turkey's Runaway Anti-Semitism,” Gatestone Institute, March 10, 2016, https://www.gate stoneinstitute.org/7564/turkey-anti-semitism; B. Uzay, “Turkey, where are your Jews?” Israel National News, April 12, 2017, https://www.israelnationalnews.com/Articles/Article.aspx/20389.

26 The two main Turkish journalists who denounces AKP's antisemitic rhetoric are Burak Bekdil, a fellow at The Middle East Forum and an author at the Gatestone Institute International Policy Council, and Uzay Bulut, a Fellow at The Middle East Forum and an Associate Fellow at The Philos Project which claims to be "dedicated to promote positive Christian engagement in the Middle East,” cf. https://philosproject.org/about/ (accessed July 17, 2019). 


\section{What Must Be Done to Combat Antisemitism in Turkey?}

Is it even possible to contend against the widespread antisemitism in Turkey? What direction should the struggle take? Before all else, it is necessary to emphasize a fundamental reality. The Turkish public and establishment does not see the existence of antisemitism as a problem to be solved. Thus, the first step must be to persuade them that it is indeed a problem and a serious one at that. This can be done with an action plan that brings together a great number of parties in order to form a strong, united front. First and foremost, this would mean the leaders of Turkey's Jewish community and civil society organizations within the country that concern themselves with human rights violations and hate speech, as well as a broad and ongoing campaign by American Jewish organizations and the identifying and publicizing of antisemitic publications and public declarations, along with calls to punish those disseminating them. Yet, it must be kept in mind that this method is the strategy of escalation, of "entering the fray." It must be kept in mind because such an active strategy will carry with it a number of serious dangers, including the engaging in an impossible to win fight with the Islamist press and the likelihood that any such struggle will provoke violent reprisals against Turkish Jews by the Islamist sector's radical fringes. Furthermore, such a struggle is unlikely to bear fruit so long as allegedly "objective" criticism of "Zionism" and "Israel"-both of which possess strongly negative, near demonic meaning for a significant part of the Turkish publichave a central place in the antisemitic discourse within the country. This is because of the consensus in nearly every part of Turkish society that the State of Israel is a "terror state" engaged in "colonizing" Muslim and Arab lands.

Any strategy developed by Jewish activists or opinion leaders in Turkey to combat anti-Israel and anti-Zionist rhetoric is by definition doomed to failure, since even the non-Jewish civil society institutions, activists, and journalists who are inclined to support such activities hesitate to voice their support, preferring to remain silently on the sidelines out of the justified fear that they will immediately be accused of being "Zionists" or "Israel lovers," appellations that in Turkey can irreparably damage their reputations and, hence, their careers.

Ultimately, we must be realistic. The leaders of Turkey's dwindling Jewish community do not wish to undertake any active struggle against antisemitism, for to do so, they rightly believe, is not likely to bring about any improvement in their situation; on the contrary, it might very well make it much worse. If they decide publicly for an active approach to combat antisemitism, they will be accused by Turkey's political establishment of tarnishing the image of Turkey 
by portraying it as an antisemitic country where Jews are under pressure and fear and are immigrating in increasing numbers to Israel, something which the news agencies are repeating more and more these days. The Turkish Jewish community leaders have never, never officially protested the widely spread antisemitic publications and statements, quite to the contrary. If we travel back in time to 1992, we will see that they have denied its existence since acknowledging it officially will mean that Turkey's ever-loyal-model minority community is joining the ranks of the "anti-Turkey coalition," something which is inconceivable. Therefore the struggle against antisemitism in Turkey will not and cannot be transformed from its current "soft sell" approach of measured and restrained condemnation into an active campaign that insists on punishment for the purveyors of such. The only thing that can be done under current conditions is to acknowledge Turkish antisemitism as an intellectual problem and thus fight it through the press in the hopes of eventually generating sufficient pressure among the country's decision makers to act.

Rifat Bali is an independent scholar specializing in the history of Turkish Jewry. He is an associate member of the Alberto-Benveniste Centre for Sephardic Studies and the Sociocultural History of the Jews (Universite Paris/Sorbonne). He is the winner of the Alberto Benveniste Research Award (Paris) for 2009 for his publications on Turkish Jewry and of the Yunus Nadi (İstanbul) 2005 and 2008 awards for research in social sciences with two of his books.

\section{References}

Ahren, Raphael. “Erdoğan Calls Zionism a 'Crime Against Humanity'.” The Times of Israel, February 28, 2013. https://www.timesofisrael.com/erdogan-calls-zionism-a-crime-againsthumanity/.

Ahren, Raphael. "Erdogan Rebuffs Anti-Semite Claims but Lashes Israel for 'Massacre'." The Times of Israel, September 23, 2014. https://www.timesofisrael.com/erdogan-rebuffsanti-semite-claims-but-lashes-israel-for-massacre/.

Ahren, Raphael. “Turkish MP: Erdoğan's Anti-semitism Difficult to Reverse.” The Times of Israel, February 5, 2014. https://www.timesofisrael.com/turkish-mp-erdogans-anti-semi tism-difficult-to-reverse/.

Axiarlis, Evangelia. Political Islam and the Secular State in Turkey: Democracy, Reform and the Justice and Development Party. New York: I. B. Tauris, 2014.

Baer, Marc David. "An Enemy Old and New: The Dönme, Anti-Semitism, and Conspiracy Theories in the Ottoman Empire and Turkish Republic." Jewish Quarterly Review 103, no. 4 (2013): 523-55. 
Baer, Marc David. "Erdogan Accuses Germany of Echoing the Nazis-But His Own Record on Anti-Semitism is Shameful." LSE European Politics and Policy (EUROPP) Blog. Issued April 13, 2017. Accessed August 7, 2020. http://eprints.lse.ac.uk/75701.

Bali, Rıfat N. 1934 Trakya Olayları. 2nd ed. Istanbul: Libra Kitap, 2012 [in Turkish].

Bali, Rıfat N. Antisemitism and Conspiracy Theories in Turkey. Istanbul: Libra Kitap, 2013.

Bali, Rıfat N. Cumhuriyet Yıllarında Türkiye Yahudileri: Bir Türkleştirme Serüveni (1923-1945). Istanbul: İletişim Yayınları, 1999 [in Turkish].

Bali, Rifat N. Model Citizens of the State: The Jews of Turkey During the Multi-Party Period. Translated by Paul F. Bessemer. Madison: Fairleigh Dickinson University Press, 2014.

Bali, Rifat N. A Scapegoat For All Seasons: The Dönmes or Crypto-Jews of Turkey. Istanbul: The Isis Press, 2008.

Bali, Rifat N. The Wealth Tax (Varlık Vergisi) Affair: Documents From the British National Archives. Istanbul: Libra Kitap, 2012.

Bayraktar, Hatice. Salamon und Rabeka: Judenstereotype in Karikaturen der türkischen Zeitschriften "Akbaba," "Karikatür" und "Milli Inkilap" 1933-1945. Berlin: Klaus Schwarz, 2006.

Bayraktar, Hatice. "Zweideutige Individuen in Schlechter Absicht": Die antisemitischen Ausschreitungen in Thrakien 1934 und ihre Hintergründe. Berlin: Klaus Schwarz, 2011.

Bekdil, Burak. “How Turkey Plans to 'Combat Anti-Semitism'.” Middle East Forum, September 25, 2014. http://www.meforum.org/4833/how-turkey-plans-to-combat-antisemitism.

Bekdil, Burak. “Turkey’s Runaway Anti-Semitism.” Gatestone Institute, March 10, 2016. https://www.gatestoneinstitute.org/7564/turkey-anti-semitism.

Çağaptay, Soner. The New Sultan: Erdogan and the Crisis of Modern Turkey. New York: I.B. Tauris, 2017.

Cizre, Ümit, ed. Secular and Islamic Politics in Turkey: The Making of the Justice and Development Party. London: Routledge, 2007.

Cohen Yanarocak, Hay Eytan. "Decoding the 'Payitaht Abdülhamid'." Turkeyscope 1, no. 5 (March 2017): 4-7, https://dayan.org/content/decoding-payitaht-abd\%C3\%BClhamid.

Gürcanlı, Zeynep. “Cumhurbaşkanı Sofrasına Mısıroğlu'nun davetine CHP'den sert tepki.” Hürriyet, August 18, 2015. http://www.hurriyet.com.tr/cumhurbaskani-sofrasina-mis iroglunu-davetine-chpden-sert-tepki-29844266 [in Turkish].

Johnson, Bridget. "Anti-Semitism in Erdoğan's Turkey is a Feature, Not a Bug." Fox News, October 25, 2017. http://www.foxnews.com/opinion/2017/10/25/anti-semitism-in-erdo gan-s-turkey-is-feature-not-bug.html.

Karslı, Öznur and Kenan Butakım. "Ve Erdoğan sahnede!” Vatan, May 2, 2012 [in Turkish].

Kozan, Ümit. “işste Akil İnsanlar Heyeti.” Hürriyet, April 4, 2013. http://www.hurriyet.com.tr/ iste-akil-insanlar-heyeti-22957853 [in Turkish].

MEMRI. "Islamist Turkish President Erdoğan Says A 'Mastermind' Is Plotting Again Turkey." Special Dispatch no. 6021. Issued April 14, 2015. Accessed August 7, 2020. https://www. memri.org/reports/islamist-turkish-president-erdogan-says-mastermind-plotting-againstturkey-antisemitic.

MEMRI. "Turkish State-Owned Network Airs Television Drama Series." Special Dispatch no. 7027. Issued July 26, 2017. Accessed 7, 2020. https://www.memri.org/reports/turk ish-state-owned-network-airs-television-drama-series-depicting-jews-murderous. 
N.N. “4. Necip Fazıl Ödülleri sahiplerini buldu.” Sabah, December 15, 2017. https://www. sabah.com.tr/kultur-sanat/2017/12/15/4-necip-fazil-odulleri-sahiplerini-buldu [in Turkish].

N.N. "Government Pledges to Ensure the Safety of Jewish Community in Turkey." Daily Sabah, July 26, 2014. https://www.dailysabah.com/politics/2014/07/26/government-pledges-totake-care-of-jewish-community-in-turkey.

N.N. "Turkish Film "Mastermind” Purports to Reveal Jewish Conspiracy." YnetNews, May 2, 2015. https://www.ynetnews.com/articles/0,7340,L-4652817,00.html.

N.N. “Turkey's Jews Are under my Protection: Turkish Prime Minister.” Hürriyet, June 22, 2012. http://www.hurriyetdailynews.com/turkeys-jews-are-under-my-protection-turkish-pm23788.

N.N. "Yiğit Bulut: Türk ekonomisinden tek çakıl taşı koparamayacaklar." Haberler, September 26, 2016. https://www.haberler.com/yigit-bulut-turk-ekonomisinden-tek-cakiltasi-8804639-haberi/ [in Turkish].

Olivier-Mallet, Laurent. “Karikatür Dergisinde Yahudilerle İlgili Karikatürler (1936-1948).” Toplumsal Tarih 34 (October 1996): 26-33 [in Turkish].

Ökte, Faik. The Tragedy of the Capital Tax. Translated by Geoffrey Cox. London: Croom Helm, 1987.

Pekesen, Berna. Nationalismus, Türkisierung und das Ende der jüdischen Gemeinden in Thrakien, 1918-1942. Munich: Oldenburg, 2012.

Presidency of the Republic of Turkey. "President Erdoğan Addresses CFR.” Issued September 23, 2014. Accessed August 7, 2020. https://www.tccb.gov.tr/en/news/542/ 3249/president-erdogan-addresses-cfr.html.

Rosenberg, Yair. "Will Obama Condemn The Mainstreaming of Anti-Semitism by Turkey's Ruling Party?" Tablet Magazine, March 20, 2015. http://www.tabletmag.com/scroll/ 189783/will-obama-condemn-the-mainstreaming-of-anti-semitism-by-turkeys-ruling-party.

Uzay, Bulut. “Turkey, Where are Your Jews?” Israel National News, April 12, 2017. https:// www.israelnationalnews.com/Articles/Article.aspx/20389.

Wilson, Simone. "At a Breaking Point in Turkey: Should Jews Stay or Should We Go?" Jewish Journal, March 18, 2015. http://jewishjournal.com/cover_story/164955/.

Yavuz, M. Hakan, ed. The Emergence of A New Turkey: Democracy and the AK Parti. Salt Lake City: University of Utah Press, 2006. 
